\title{
Thomas Piketty*
}

\section{About Capital, Socialism and Ideology}

https://doi.org/10.1515/auk-2021-0008

Abstract: In this article, I attempt to briefly clarify a number of issues regarding what I have tried to achieve in my book Capital and Ideology. I also comment on the many limitations behind such a project, whose main objective is to stimulate further research on the global history of inequality regimes, at the intersection of economic, social and political history. Lastly, I address some of the many stimulating points raised in the reviews, particularly regarding the nature of participatory socialism and its incompleteness.

Keywords: ideological indeterminacy, Swedish revolution, trifunctional societies, propretarian societies, social-democratic societies, participatory socialism, Brahmin left, merchant right

I am most grateful to the editors of Analyse \& Kritik for putting together such a stimulating set of review essays about my book Capital and Ideology. There is no way I can do justice to the richness of each review, and it is impossible to address all the stimulating points that they raise. I would like however to take this opportunity to briefly clarify a limited number of issues regarding what I have tried to achieve in this book and the many limitations behind such a project.

\section{Elements for a Global History of Inequality Regimes}

In Capital and Ideology, I attempt to provide some elements for a global history of inequality regimes, that is, a history of the systems and institutions by which inequality is justified and structured, from premodern trifunctional and slave societies to modern postcolonial and hyper-capitalist ones. One of main conclusions is that inequality is primarily political and ideological, rather than economic and technological. This is illustrated by the large diversity of socio-historical trajecto-

*Corresponding author: Thomas Piketty, Ecole d'Economie de Paris, Paris, France, email: thomas.piketty@psemail.eu 
ries which I uncover and analyze over time and across the five continents. I also stress that there exists a long-run trend toward more equality, and I attempt to draw positive and constructive lessons for the future. This is fundamentally an optimistic book, in the sense that I believe in the possibility to learn from history and to pursue the march towards equality.

Obviously, such a global historical project is never-ending. No book can exhaust so vast a subject. All my conclusions are tentative and fragile, by their very nature. They are based on research that needs to be supplemented and extended in the future. My objective is certainly not to close the subject, but rather to help readers clarify their own ideas and their own ideologies of social equality and inequality and to stimulate further reflection on these issues.

In particular, despite my best efforts to decenter our gaze, I have to say that this book remains unbalanced-somewhat less so than my previous book but still quite unbalanced on the whole. I try in Capital and Ideology to offer a global and connected perspective on the history of inequality regimes. I stress throughout the book the central role of the colonial and post-colonial legacy for the understanding of the past, the present and the future (an issue on which I will further return below, when I discuss the question of reparations). Nevertheless, the experiences of France, Europe and the United States are constantly cited in Capital and Ideology, much more so than their demographic weight warrants. The experiences of Africa, Latin America and Asia are also addressed, but not with the same level of precision and knowledge. Jack Goody, in his book The Theft of History (2006), rightly denounced the often-irresistible temptation to write history from a western-centric point of view, which afflicts even well-intentioned social scientists. Writers routinely attribute to Europe and America inventions they did not invent or even cultural practices such as courtly love, the love of liberty, filial affection, the nuclear family, humanism, and democracy. I have tried to avoid this bias, but I am not sure I fully succeeded.

The reason is simple and should be acknowledged: my gaze is profoundly influenced by my cultural roots, the limits of my knowledge, and above all by the serious weakness of my linguistic competence. This book is the work of an author who reads fluently only in French and English and who is familiar with only a limited range of primary sources. Yet this study ranges widely-perhaps too widely-and I beg the pardon of specialists in other fields for the approximations and condensations they will find. I hope that this work will soon be complemented and superseded by many others, which will add to our understanding of specific inequality regimes, especially those in the many geographical and cultural regions and traditions poorly covered by this work. For instance, Andreas Langenohl rightly stresses in his review that my book would have benefited from a closer look at recent interventions in economic anthropology that deal with 'economic 
citizenship' in the Global South. I fully agree with this and I am most grateful for the many constructive suggestions provided by this review and the other essays, which will greatly help me to include broader perspectives into my future work.

\section{Power, Ideology and Indeterminacy: Borders and Property}

Let me now come to the main point that I would like to clarify in this essay. Although I believe in the role of ideas and ideology in shaping the global history of inequality regimes, I certainly do not think that ideas alone can change the world. Without major shifts in the balance of power and material forces, ideologies have little impact, as rightly argued by Katharina Pistor in her review. But without specific ideas and ideologies on how to transform the world, material and social forces alone do not know where to turn.

Throughout my book, I emphasize that the balance of power and the (often violent) political confrontation between antagonist social interests play a central role in the transformation of inequality regimes. For instance, the beginning of the end of slaveist societies in the Atlantic world starts with the 1791 slave revolt in Saint-Domingue-not in enlightened discussions in Parisian salons or in parliamentary assemblies. The occurrence of other revolts (e.g. in Guadeloupe in 1802 or in Jamaica in 1831) and the threat of new ones also played a central role in the British and French abolitions of 1833 and 1848. In the same manner, the end of aristocratic privileges in European societies of orders was to a large extent the consequence of revolutionary events and peasant revolts (e.g. in France in 1788-1789). During the late 19f, century and the first half of the $20^{\text {th }}$ century, the balance of power between capital owners and industrial workers was redefined by trade-union mobilization and social struggles, the Bolshevik revolution and the existence of a communist threat. Without such dramatic shifts in the balance of power, it is difficult to see how the proprietarian societies of 1914 would have been replaced by social-democratic societies in Western Europe after 1945. At the global level, I also build upon an extensive historiography in order to show that the rise of the West over the 1700-1900 period was largely due to the superior military and fiscal capacities of European state powers. Similarly, differences in collective mobilization capabilities and military strength played no small role in independence wars and the end of colonial societies. The US Civil War put an end to slavery in the US in 1865, and it took enormous African-American mobilization to end racial discrimination in 1964-1965. And so on. 
At the same time, I also stress throughout the book that the balance of material power and social forces needs to be supplemented with the power of ideas and ideology. In other words, the class struggle theory of history, no matter how relevant it still is, ought to be reframed and rebalanced with the ideological struggle theory. This is the general perspective that I attempt to develop in Capital and Ideology.

Ideas and ideologies matter a great deal, both before and after the seizure of power. First, ideas and ideologies play a central role in social struggles and political mobilizations. In order to build a sense of solidarity and common identity (e.g. among rebellious slaves, landless peasants or industrial workers), one needs some common views about how society should be reorganized. This does not need to be a full-fledged political program, but at least some broad lines of action must be agreed upon, no matter how rudimentary. The point is that there is generally a large diversity of ideologies and narratives that can be developed in order to support social mobilizations. They are never fully determined by society's socioeconomic structure, and they matter for the success of the social struggles and mobilizations.

Next, and maybe most importantly, ideological struggles matter because the practical implementation of a new political and social order (after the success of mobilization and the seizure of power) will always be accompanied by some form of ideological indeterminacy or incompleteness. That is, whatever the balance of power might be, there will remain some fundamental indeterminacy about the most desirable manner to reorganize society and to redefine power relations after the conquest of power.

Ideological indeterminacy stems from the fact that the core issues that need to be addressed-especially the border question and the property question, following the terminology used in my book ${ }^{1}$-are so complex and open-ended that they can never be fully determined by material interests alone. Of course it is possible to learn over time (both from historical experience and through political deliberation and confrontation) about the various institutional arrangements which can be used

\footnotetext{
1 "To simplify, we can say that every inequality regime, every ideology of equality and inequality, rests on both a theory of borders and a theory of property. The border question is of primary importance. Every society must explain who belongs to the human political community it comprises and who does not, what territory it governs under what institutions, and how it will organize its relations with other communities within the universal human community (which, depending on the ideology involved, may or may not be explicitly acknowledged). The border question and the political regime question are of course closely linked. The answer to the border question also has significant implications for social inequality, especially between citizens and non-citizens. The property question must also be answered. What is a person allowed to own? Can one person own others? Can he or she own land, buildings, firms, natural resources, knowledge, financial assets, and/or public debt? What practical guidelines and laws should govern relations between owners of property and non-owners?” (Piketty 2020, 5).
} 
to regulate the border regime and the property regime (as well as the educational system, the fiscal system, and so on). This process of learning about justice and institutions has been at work for centuries, and in my view contributes to explain the long-run trend toward more equality. But it will always be incomplete and imperfect, so that ideological struggles and disagreements will continue.

Let me take an exemple. By the end of 1917 and the beginning of 1918, the balance of power allowed Russian Bolsheviks to take control of the situation in Petrograd (and gradually all over Russia) and to start building what they considered to be the basis for the first 'proletarian State' in history. This does not imply, however, that they had clear and consensual ideas on how the new social and political order should be organized. From then on, multiple possible political and institutional paths were possible. Who will rule the new bureaucratic ruling class, and by which electoral processes or other political mechanisms will it be held accountable? Should there be multiple factions within the ruling party, and what should be their role? What will be the power of the soviets, the trade-unions, what will be the proper hierarchy of wages and material advantages, and how will it be controlled and enforced? How will political power and central planning be organized between the various soviet republics, and between urban and rural territories? How should the 'proletarian State' address the issues of gender inequality, family relations, ethnolinguistic and religious diversity within the soviet federation? Marxist-Leninist ideology-as understood by the social and political actors of the time-did provide a number of answers, but there were lots of gaps. Lessons from the French Revolution of 1789, European Revolutions of 1848 or the Paris Commune of 1871 were often invoked, but offered limited practical guidance for the concrete institutional choices that were to be made. Different individuals and social groups within the Bolsheviks and Russian society at large naturally had widely conflicting views about these complex questions, depending on their pre-revolutionary intellectual and sociopolitical trajectories, and depending also how they reacted to the unfolding of events. My general point is that the choices that were made and the chaotic trajectory that finally occurred were not the only possible ones, and that ideological indeterminacy played a critical role in these historical processes.

To put it another way: social class position, as important as it is, is not enough to forge a theory of the just society, a theory of property, a theory of borders, a theory of taxes, of education, wages, or democracy. Without precise answers to these complex questions, without a clear strategy of political experimentation and social learning, struggle does not know where to turn politically. Once power is seized, this lacuna will be filled by specific political-ideological constructs and institutional choices, some of which might turn to be more oppressive than those that were overthrown. For a given class position and social experience, different 
individuals will espouse different views on borders and property, depending on their political experience, the deliberative processes they have been exposed to, and their own subjective and emotional experience. Class struggles and ideological struggles are intimately related, but they are never fully aligned. There is always a large autonomy of the ideological sphere, especially in periods of crisis and in times when the old balance of power is replaced by a new one and when novel unanswered challenges emerge.

\section{Ideology, the French Revolution and the Swedish Revolution}

Where do ideologies come from? I certainly do not attempt to offer in my book anything close to a satisfactory answer to such a complex question, let alone a general theory. More modestly, I study specific socio-historical episodes of ideological struggles and try to identify the main forces at play. In particular, I stress the role played by the memory of past institutional choices (or the lack thereof) and the diffusion of knowledge and experiences across national and imperial trajectories.

I also argue that in order to analyze these learning processes, it is fruitful to go beyond abstract principles about equality, liberty, rights and justice, and to focus upon the concrete institutional devices that societies need to make in order to translate these general principles into the social reality: legal systems and electoral rules, tax rates and tax schedules, educational resources and social spending, and so on. Without these, institutions and ideologies are mere empty shells, incapable of effecting real social change or inspiring lasting allegiance.

For instance, when I analyze the achievements and the limitations of the French Revolution in relation to the redistribution of property, I show that some very concrete proposals were put forward about new income and inheritance tax schedules designed to replace the old tax system and to finance minimum income or capital endowment to all. Many such brochures were published and discussed, not only by famous actors like Condorcet or Paine, but also by less well-known authors such as Graslin or Lacoste, who explicitly proposed to set graduated tax schedules with tax rates rising from less than $5 \%$ for individuals with incomes and inheritances below average up to 70\%-80\% for those with incomes and inheritances several hundred times above average. These tax schedules turn out to be very close to those that were adopted and implemented in the United States and in Western European countries during the $20^{\text {th }}$ century (especially between 1920 and 1980). However, no such progressive tax system was adopted during the French Revolution, with the exception of some limited attempt in 1793-1794 in the form 
of graduated forced war-finance loans. The tax system which emerged from the French Revolution and applied until 1914 was for the most part a flat tax system, which contributes to explain the rise of wealth concentration that occurred in France during the $19^{\text {th }}$ century and up until World War I.

In order to analyze this historical sequence, I again emphasize the fact that several trajectories were possible, and that it would be a mistake to look at these events in a deterministic manner. It is not difficult to imagine a slightly different course of events in 1792-1798 which would have led to more extensive experimentation and diffusion of progressive fiscal institutions. The magnitude and speed of the post-WWI international diffusion of tax progressivity, as well as the velocity of the post-1980 retreat, point in this direction. In the case of the French Revolution, however, the material and ideological balance of power strongly bent in the other direction. Many actors (e.g. Montesquieu) were already afraid that the centralization of the judicial system over such a large territory and population (given the transportation and communication system of the time) was already a risky adventure that could give rise to an excessive concentration of state power. In this context, the standard proprietarian argument according to which opening up the Pandora box of progressive taxation will lead to endless chaos proved to be especially powerful.

More generally, I attempt in my book to show the plausibility of each set of ideas and ideologies. Of course, this does not mean that I put all ideologies on the same scale. In the case of progressive taxation, I try to explain why I find the Pandora box argument ultimately unconvincing, and why I consider that it should be reopened. Namely, in light of the $20^{\text {th }}$ century international experience with tax progressivity, and after a critical examination of the positive historical evidence associated to this experience, I argue that the desirable level of income and wealth tax progressivity is very high (up to 80\%-90\% tax rates for very top income and wealth levels), that the true historical source of prosperity lies in education and equality (rather than in the pursuit of trickle-down inequality), and that we should rely on democratic deliberation to set the right level of fiscal progressivity (rather than on constitutional limitations). However, I always try to make clear that the available evidence is insufficient and imperfect, so that opposite views will always keep some plausibility. In that sense, my analysis of ideological struggles attempts to go beyond Marxian notions such as 'false consciousness'. Because the institutional choices that human societies need to make are so complex, there is ample room for rational disagreement and democratic deliberation.

Let me now take the example of the 'Swedish revolution'. Following the work of Erik Bengtsonn, I stress that the inequality regime which was in place in Sweden during the 1865-1911 period was one of the most extreme European proprietarian 
societies ever observed (and arguable the most extreme). It is not only that voting rights were restricted to the richest segments of society (namely, approximately the top $20 \%$ of male taxpayers of the time)-a feature which one finds in most European societies in the $19^{\text {th }}$ century. What is striking in the case of Sweden is that the wealth-owning class was able to impose a much more sophisticated system tying political rights and property ownership, in the sense that the actual number of voting rights (the fyrkar) was roughly proportional to the amount of wealth and the level of taxes, up to 54 votes in legislative elections and 100 votes in urban municipal elections. There was no such celling in rural municipal elections, so that around 1880-1900 there were several dozen municipalities where one taxpayer had more than $50 \%$ of the vote (including the municipality of the then Prime Minister, Count Arvid Posse). In municipal elections, corporations also had the right to vote, again on the basis of their assets and taxes-something that even the most selfconfident international businesses today do not dare asking for in the countries where they operate (though they sometime find alternative ways to obtain the same outcome). This peculiar Swedish electoral system was finally changed in 1911, and universal suffrage was imposed in 1921, following an intense popular mobilization. The Swedish social-democrats (SAP) took power in 1932. They then ruled the country for most of the following sixty years and put in place what has come to be viewed as one of the most egalitarian societies in history (and rightly so, in spite of its many limitations). The Swedish transition perfectly illustrates the key role of social mobilization and political ideology in order to induce a dramatic change in the basic organization of society over a relatively brief period.

Needless to say, I certainly do not claim that I have a full-fledged theory explaining why this major ideological transformation happened the way it did. I explore a number of explanations, none of which fully exhausts the discussion. First, I stress that to some extent a similar politico-ideological transformation driven by social mobilization, working-class struggle and socialist/social-democratic ideology happened in other Western European societies between 1890 and 1950 (albeit with different intensities). Next, the fact that the wealth-owning classes went so far in the constitutionalisation of their political power in the case of Sweden certainly contributed to stimulate the sense of injustice and the mobilization of the Swedish working class. I also stress the fact that the process of state centralization and administrative capacity building started very early in Sweden. As early as 1750, the Swedish state started to organize very sophisticated censuses, and was in many ways well ahead of Britain or France. By 1850-1900, the Swedish state had developed an impressive system of property and income registers, which at the time were used to distribute large voting rights to the upper class and to enforce a highly inegalitarian political and social order. Swedish social-democrats were then able to put this state capacity to the service of a completely different political project. 
Namely, property and income registers were used to make affluent taxpayers pay high progressive taxes in order to pay a relatively egalitarian education and health system. Workers rights were also put in place in companies together with social insurance schemes in order to counterbalance the power of property owners.

One of the general lessons from this experience is the following. In a sense, the process of state centralization opens up more coercive opportunities for the elite than traditional systems of local domination based upon a mixture of property and regalian rights at the local level. However, this same process of state centralization also opens the way for the removal of elite power, depending on who controls the state and in the name of which ideology. In the case of Sweden, a proper analysis of the transition would also require to pay close attention to the powerful strategy of political mobilization developed by the trade-unions and the socialdemocrats, including the construction of a strong working-class identity, industrialwork culture and a comprehensive policy platform. But here again nothing was written in advance, and nothing is written for ever. The specific forms taken by class struggles and ideological struggles played a key role, and the same conclusion will apply in the future.

I should also make clear that my account of ideological change is incomplete in many ways, and should be supplemented by substantial additional research. For instance, I may tend to neglect the role of the economics profession itself in the transformation of dominant ideology. They stressed in particular the role of 'rational-expectations macroeconomics' in order to explain ideological change during the 1970s-1980s and the movement toward financialization. In my book, in order to explain turning points like the 'conservative revolution' of the 1980s, I tend to emphasize the role of historical and political events and the way they were interpreted and instrumentalized by the various social actors. For instance, in this case, I stress the role of the experience of 'stagflation' during the 1970s (mixture of high inflation and low growth), the catching up of the US and the UK by other industrial nations over the 1950-1980 period, as well as the decay and fall of the Soviet Bloc over the 1970-1990 period. However, I fully agree that the narratives provided by economists also play a role in these transformations and could be better integrated into the historical analysis.

\section{Trifunctional Societies, Proprietarian Societies, Social-Democratic Societies}

In order to better understand the global history of inequality regimes, I also describe in my book a number of 'ideal types' of societies, including 'trifunctional societies' 
(i.e. societies based upon three major socio-political classes: the clergy, the nobility and the third estate), 'proprietarian societies' (based in principle upon a strict demarcation between property rights and regalian powers) and 'social-democratic societies' (which emerged in a number of countries over the course of the $20^{\text {th }}$ century, particularly but not only in Western and Northern Europe).

I should stress however that these notions should really be viewed as iideal types', i.e. as useful simplifications of the reality, and certainly not as satisfactory descriptions of existing societies, which in practice are always much more complex.

In particular, 'trifunctional societies' were much more diversified and stratified than what the overly simplistic 'ternary' structure might suggest. As I try to make clear in my study of both Europe and India, the notion of a 'trifunctional' (or sometime 'quadrifunctional', in the case of India) society should be analyzed as a piece of normative political ideology, not as a sociological description of the world. This is perfectly transparent in the case of the Manusmriti in India (a highly influential political treatise written by a group of brahmins between $2^{\text {nd }}$ century BCE and $1^{\text {st }}$ century CE, and which played a central role as the official 'description' of the caste system since then, even though it was much more a 'prescription' than a 'description'). This is equally clear regarding the first religious and political texts about the trifunctional organization of society authored by European bishops around the $11^{\text {th }}-12^{\text {th }}$ centuries CE. In practice, as I make clear in my book, premodern societies both in India and Europe never conformed the wishes of Hindu brahmins or Christian bishops. In particular, these societies involved highly diversified rural and urban occupational groups, complex power structures and a continuum of small, medium and large property owners. In addition, the long-term process of demographic and commercial expansion and the forces of economic growth obviously played a central role in the gradual weakening of ternary elites and the formation of proprietarian societies.

The point, however, is that trifunctional political ideologies also played for a very long time a powerful role in the transformation and organization of these societies. For instance, the British House of Lords (an institution based on temporal and spiritual lords and which dates back the trifunctional structure) was the dominant institution ruling the world's premier industrial and colonial empire until its fall in 1907-1908 (a fall which as I show involved major conflicts about progressive taxation and the redistribution of property). In India, it is impossible to analyze today's conflict about reservations and caste relations without studying the legacy of trifunctional (or quadrifunctional) ideology and the way British colonial censuses conducted over the 1871-1931 period contributed to rigidify the boundaries between castes (partly because colonial rules found it useful to follow the 'description' provided in texts like the Manusmriti). In a country like Sweden, one needs to wait until the constitutional reforms of 1860-1865 in order to see 
the end of separate political assemblies for the nobility, the clergy and the third estate. The interesting point here is that the replacement of trifunctional ideologies and institutions by proprietarian ideologies and institutions often came with the replacement of religious sacralization by the sacralization of property, as the case of Swedish property-based voting rights clearly illustrates.

The transition from proprietarian to social-democratic societies was to a large extent based upon a desacralization of property rights, which were counterbalanced by a number of other institutions, including universal suffrage, workers rights, and progressive taxation. It should however be remembered that today's social-democratic societies still involve strong constitutional rules limiting the ability of a popular majority to redistribute property and social power. In the view of their proponents, these constitutional rules are justified by considerations that are not completely different from those that have always been at the core of proprietarian societies: without such a constitutional protection of property, the story goes, the Pandora's box of permanent redistribution of wealth will be endlessly opened and reopened, leading to permanent chaos. On the basis of the successful $20^{\text {th }}$ century experiences with progressive taxation, I happen to believe otherwise (as I already noted), and I make constitutional and legal proposals in my book in order to further facilitate the redistribution of property. But at the same time I fully understand why proprietarian arguments bear some plausibility in the eye of many observers.

To sum up: trifunctional, proprietarian or social-democratic ideologies need to be taken seriously because they do play a central role in the evolution of the political and economic organization of human societies, in spite of the fact they often provide a relatively poor description of their sociological complexity. In order to decide how they should be organized, societies rely on simple narratives and ideologies, so that they can organize the discussion and the political confrontation of alternatives.

\section{Participatory Socialism and the Case for Social-Federalism}

Let me now take another example of ideological indeterminacy that will again illustrate the complex unfolding of beliefs systems about institutions, the property regime and the border regime. In the last chapter of my book, I build upon some of the lessons from the previous chapters and from the experience of the $20^{\text {th }}$ century (including in particular the Anglo-American experience with progressive taxation and the German-Nordic experience with codetermination and the social state) in 
order to describe how an ideal system of 'participatory socialism' could look like in the future.

Several points are in order here. First, the notion of 'participatory socialism' corresponds in my view to one of the possible trajectories which could happen in the long run, and certainly not to something that is likely to be implemented in the very short run. Given how other major transformations of inequality regimes occurred in the past, it is likely that such an important transformation would entail some major social and political crisis, which as I argue in my book could be triggered by future environmental crisis, but which I am naturally unable to predict.

Next, 'participatory socialism' is fairly different from the system of 'socialdemocratic capitalism' (or 'welfare-state capitalism') that we have today in a number of Western countries. In particular, it goes much further in terms of progressive taxation and redistribution of income and wealth, power sharing and workers rights in companies, and educational justice. It is based upon legal, fiscal and social rules that are designed to ensure a permanent circulation of property and power. However, I would argue that 'participatory socialism' is no more different from the kind of 'social-democratic capitalism' that is in place in 2000-2020 than the latter differs from the type of authoritarian-colonial capitalism that was in place around 1900-1910. In other words, inequality regimes have already changed a lot in the past, and it makes sense to think of the possible next steps in this perspective.

It is worth noting that support for worker democracy and increased voting rights in corporate boards is currently rising across the world, including in the US and in the UK. It is by no means impossible that German-Nordic codetermination systems will be extended and deepened in the coming decades. Just like many transformations which occurred over the 1900-2020 period, this will probably involve major political and social crisis, and this certainly require a number of constitutional changes. But this does mean that this will not happen.

This model of participatory socialism maintains the existence of small- and medium-sized private property in order to avoid the pitfalls of excessive state power centralization and to allow room for the expression of individual aspirations. A natural question is whether this might jeopardize the egalitarian ethos that I am defending. I do not think so, because participatory socialism comes with a redefinition of the bundle of rights usually associated with pure private property. What I am proposing is closer to social property, in the sense that workers should have very substantial decision rights as workers, including in small firms, irrespective of any capital stake. As compared to standard co-determination rules, as they were applied in Germany and Nordic countries since World War II, and whose achievements should not be overestimated, I emphasize for instance the need to 
put a ceiling on the maximum vote share that a single shareholder can hold (within the $50 \%$ of the votes going to shareholders).

In addition, I certainly do not consider the form of organization that I describe under the label of 'participatory socialism' as a final point. This is nothing more than one possible logical step in the light of the evolutions observed over the past century. This might be followed by the development of new forms of collective structures, including various types of non-profit associations, cooperative banks, local actors, etc.

For instance, as stressed by Andreas Albertsen and Kasper Lippert-Rasmussen in their review, one might think of including a fraction of the capital endowment into some sort of a 'worker fund'. I am very much open to this kind of the possibility, but only if a similar rule applies to all inherited wealth, and not only to the 'inheritance for all' component.

In his review, Martin O'Neill rightly argues that I do not pay enough attention to the proposals on 'worker funds' promoted by Rudolf Meidner (from Swedish trade-union federation LO) in the 1970s. I entirely agree with this point as well as with other points made by Martin O'Neill in his very interesting and constructive review. My intuition is that I would prefer to see institutional schemes like the 'worker fund' and other collective ownership bodies in addition to individual capital endowments and codetermination rules (rather than instead of any of them). But it is clear that there is ample room for discussion here.

From a different angle, Timur Ergen and Sebastian Kohl stress in their review that the move toward small and medium size companies is not in itself a guarantee for more equality and freedom, depending in particular on how power is exerted and job security is distributed. I do not take a strong strand on this issue, but I emphasize the need for more power sharing, whatever the size of the company.

Generally speaking, 'Socialism' is a term that has been used in widely different meanings in the past, sometime referring to a system where the state owns the means of production, and sometime referring to a system where workers control companies. The way I define 'participatory socialism' is certainly closer to the second definition, though it is novel in the way I try to combine workers rights, limited property rights, and permanent circulation of power and property via progressive taxation. But yet again I want to stress that this particular notion of 'socialism' is certainly not meant to close the discussion.

Finally, and most importantly, the notion of 'participatory socialism' attempts to address the limits of social democracy, not only regarding the redefinition of property relations at the domestic level, but also regarding the structure of global North-South inequalities as well as in terms of racial and gender divides.

This is fairly important, because the set of social-democratic policies implemented by Western countries over the 1950-1980 period largely ignored racial and 
gender issues, as well as the very unequal center-periphery relations between the richest countries (including the former colonial powers) and the poorest countries (including the newly independent countries) that were in place during this period. This is not saying that the reduction of inequality which took place in the North in the mid- $20^{\text {th }}$ century happened at the expense of South. If anything, colonial extraction was at a higher point in the $18^{\text {th }}-19^{\text {th }}$ centuries and in the early $20^{\text {th }}$ century (when inequalities were at their highest levels in the North) than in the 1950-1980 period (when inequalities were their lowest levels in the North). The removal of colonial masters in the South came together with the removal of capitalist masters in the North, and there are strong reasons for this: first because these were to some extent the same masters, and next because imperialist competition between colonial powers largely contributed to the destruction of the proprietarian-colonial order between 1914 and 1945. However it is critical to stress that the capitalist world-system remained a very unequal and hierarchical center-periphery system during the 1950-1980 period, as well of course as during the 1980-2020 period. That is, the old colonial masters were removed, but Northern countries developed new neo-colonial patterns of domination in the context of center-periphery economic relations, including when they were ruled by social-democratic parties.

To a large extent, the set of global institutions that was adopted in the aftermath of World War II was very much designed to fit the interest of dominant economic powers. For instance, the latter refused in 1947-1948 to pursue the project of an International Trade Organization when they realized that it might become too multilateral for their taste and could end up giving too much voice to countries like Brazil and India as compared to what they were ready to accept. In Capital and Ideology, I also stress that Western economic powers managed to instrumentalize global economic and financial institutions in order to impose 'shock trade liberalization' to developing countries in the 1980s-1990s, which resulted into a large fall in domestic tax revenues and had a very negative impact on the process of state building in the global South. The process of financial liberalization, 'free' capital flows and massive tax evasion that was put in place in recent decades under the leadership of rich countries (and especially European countries, sometime under the leadership of social-democrats, socialists and labour governments) also had very damaging effects in the South, even more so than in the North.

This is why the notion of 'participatory socialism' which I call for needs to include a complete rethinking of the international economic order. I describe a number of steps in this direction, but it is clear that this needs to be supplemented by much more extensive thinking and deliberation. In particular, "participatory socialism' relies on what I describe as 'social-federalism', i.e. a system of international relations that should prioritize the adoption of an equitable global tax system and a sustainable development model over the continuation of trade and capital 
flows. This requires the development of new kinds of multilateral and bilateral development treaties, including transnational assemblies based upon egalitarian principles and verifiable targets regarding social and environmental objectives. Given that the rise of Western industrial capitalism relied heavily on slavery and colonial extraction (together with other specific factors), the notion of 'social federalism' also includes a strong reliance on international justice, including the right of all countries to receive a share of taxing rights on the world's most powerful economic actors (large firms and billionaires). Here again I do not claim that such transformations will happen more smoothly than other reshufflings of the world order or domestic order in the past. They will require deep shifts in the global balance of power between competing social interests and states, which might be triggered by environmental, migration or other geopolitical crisis.

I also attempt in Capital and Ideology to put these debates on democraticsocialist federalism into historical perspective. I stress in particular the importance and plurality of the debates on European federalism which took place before and after World War II, as well as the discussions on socialist federalism that occurred in various decolonization settings (e.g. in West Africa, the Middle East and the West Indies). The general point is that there are always alternative ways to organize the world economic order and the system of borders. For instance, colonial empires played a key role in the industrial revolution and in the rise of the West, and it is very difficult to imagine today how alternative development trajectories could have taken place (e.g. industrialization with free migration, free labour and a more equitable balance of power and distribution of wealth at the world level). It is important, however, to stress the possibility of alternative trajectories, including at the global level, for the past and even more so for the future.

\section{Participatory Socialism and the Case for Reparations}

I stress in my book the need to articulate a universal approach to social justice and redistribution together with a view emphasizing the need for addressing past discriminations and prejudices (including in the form of reparations).

Let me take an example. In order to compensate former French slave owners for their loss of property, the French state decided in 1825 to impose on the newly independent state of Haïti an enormous public debt (around three years of Haiiti's total annual production of the time). As I recall in my book, the French state also attempted in a different context (namely, the Versailles treaty of 1919) to impose on Germany a tribute of similar magnitude (about $300 \%$ of GDP). The difference 
is that in the case of Haït the French state had the military capacity to enforce effective payment. Needless to say, the little island (which used to be France's colonial jewel and the largest slave concentration in the Atlantic world before the 1791 slave revolt) could not reimburse such a large debt in one year, nor in a few years. A consortium of French bankers (later replaced by U.S. bankers) offered to refinance the debt at high interest rates, and Haïti ended up repaying enormous flows of resources to its former slave-owners during more than a century, between 1825 and 1950.

In France, one typical attitude about this shameful episode, when it is not wholly ignored, is that this all happened a long time ago, and that it is now too late to do anything. One problem with this attitude is that we are still implementing today reparations for expropriations and other injustices that happened during World War II, or even sometime during World War I. With this kind of premise based on double standards, it is very difficult to build some commonly agreed norms of justice.

Of course the same issue also arises for other reparations related to various post-colonial, post-slavery contexts. Both in Britain and France, the abolitions of 1833 and 1848 entailed enormous payments to former slave owners (and nothing at all for slaves, who were inflicted various schemes of quasi-forced labour, which in former French colonies were in place until 1946). In 2001, a French MP from Guyane (Christiane Taubira) proposed to set up a commission on land reform and reparations in former French slave islands and territories (Martinique, Guadeloupe, Reunion, Guyane). The parliamentary majority of the time, in spite of being from the 'left' (socialists, communists, greens), adopted a statement according to which slave trade was recognized as a crime against mankind, but refused to create the commission.

In the US context, it is well known that the promise that was made to former slaves at the end of the Civil War ('one mule and 40 acres of land') was never honored when the war was over. One century later, when legal racial discrimination finally came to an end in 1964-1965, there was again no reparation of any sort to African-Americans for the prejudice that they were exposed to for decades and centuries. This does not imply however that this will never happen. After decades of denial, US Congress adopted in 1988 a legislation including a 20,000 \$ reparation for all Japanese-Americans that were imprisoned during World War II and that were still alive at that time. In 1999, the French National Assembly created a new commission in order to compensate the victims of anti-Semitic spoliations during World War II (and their descendants).

The issue of reparations is also important because it provides a clear illustration of the more general theme of ideological indeterminacy. That is, nobody has a perfect formula to define justice in this context (nor in other contexts); yet 
one cannot ignore the question simply because it is too complex. Unsurprisingly, class positions and the balance of power do play an important role in shaping the political battles and the outcomes about rep arations. But these forces are insufficient as such to determine the right balance between the logic of reparations-based justice and the logic of forward-looking distributive justice (independently of one's origins). One needs to rely on democratic deliberation and historical evidence in order to reach the best possible compromise and to build norms of justice that can be discussed, improved, shared and agreed upon as widely as possible.

Another illustration of this general issue is the question of quotas for formerly discriminated social groups. For instance, an ambitious system of reservations was put in place in post-independence India in order to provide seats in higher education, public employment and elected positions for Dalits and Avisatis (former untouchables and aboriginals). In Capital and Ideology, I analyze in some length the achievements and limitations of this policy-by far the largest affirmative action program that was ever implemented in history. On the one hand, this policy did contribute to reduce the level of inequality between formerly discriminated groups and the rest of Indian society-more so for instance than the inequality between Blacks and Whites in the United States. But on the other hand, this policy had strong limitations.

To a large extent, capitalist growth has entrenched and transformed (rather than erased) the ideology of caste and race in India, and reservations were not sufficient to erase long-standing inequality between Dalits, Avisatis and and the rest of society. In my book, I emphasize that these reservations (which by construction could not benefit more than a tiny fraction of the disadvantaged social groups) often served as an excuse for large segments of the Indian elite (including part of the leadership of the India National Congress) not to pay the taxes that would have been necessary in order to finance a proper system of social services (education, health, basic infrastructure) open to everyone.

I also stress that an ambitious redistribution of property would probably have been necessary (and would still be necessary) in order to confront the kind of entrenched inequality regime which post-independence India inherited from its ancient and colonial past. Some redistributions of property were carried out in the land reform programs implemented by communist regional governments in Kerala or West Bengal, but they never received much support at the federal level. From an ideological viewpoint, it is worth noting that Dalit leaders like Ambelkar have always been unconvinced by Marxist approaches stressing the central role of property relations and their transformation, and neglecting (in Ambelkar's view) the specific discriminations suffered by Dalits, including of course within the working class. Ambelkar was partly correct, in the sense that 'categorical inequalities' need to be addressed by 'categorical policies'. When past prejudices 
and discriminations against certain social or racial groups (or against women) are so entrenched, it is often indispensable to use some specific reparations or reservations system. It is critical however to plan in advance how such schemes are scheduled to evolve over time as past discriminations are being corrected (otherwise there is a strong risk to reify the categories at play), and to find the right balance with universal forward-looking policies such as the redistribution of income and property and open access to high-quality public services (which in the long-run are arguably more powerful than categorical policies alone). Finding an adequate compromise between these different dimensions of redistribution is not an easy task. This again requires to take ideas and ideologies seriously, and not simply as a mirror of class positions.

\section{Brahmin Left vs Merchant Right: Class, Race, Identity \& Ideology}

In the last part of Capital and Ideology, I attempt to analyze the changing structure of political cleavages since World War II, and in particular the rise of the 'Brahmin Left' and the 'Merchant Right' in Western electoral democracies. By this, I mean that the intellectual elite and the business elites now vote for two separate parties or coalitions of parties. This is a new situation that gradually developed over the 19802020 period and which differs markedly from the structure that prevailed in the 1950-1980 period, when conservatives and other right-wing parties attracted both the high-wealth and high-education elites, while social-democrats and other leftwing parties obtained their best scores among the low-wealth and low-education electorates.

I also stress that the emergence of this multiple-elites party system and the breakdown of the previous class-based party system should be analyzed in conjunction with the fall in the redistributive ambition of social-democratic platforms and ideologies since 1980-1990, as well with the rise of new political challenges and socioeconomic realities, including the rise of higher education, globalization, the decline of manufacturing, the expansion of the public sector, the emancipation of women, and the emergence of de facto multiethnic and multi-religious societies.

Let me emphasize that this analysis should be viewed as exploratory and incomplete. As Steven Pressman rightly points out in his review, the issue of the emergence of the social-nativist coalition is central and would deserve further study. In particular, one would need to study more closely the changing forms of politisation by the various social classes. I very much hope that future research will address some of these limitations. For instance, the fragmentation of the political 
system and the rise of new political parties like green/libertarian left parties and populist/xenophobic right parties have played a key role in the transformation of electoral cleavages. In many countries with many-party system the 'Brahmin Left' and 'Merchant Right' should be view as coalitions of heterogeneous parties rather than as single parties. In a collective volume co-edited with Gethin and MartinezToledano and written after the completion of Capital and Ideology, we look into more details at the changing structure of electoral cleavages and party systems in 50 electoral democracies over the 1948-2020 period, which leads us to uncover a large diversity of situations. ${ }^{2}$ At the same time, it is striking to see that the findings on 'Brahmin Left' vs 'Merchant Right' also hold in countries with predominantly two-party systems, starting with the U.S. (Democrats vs Republicans) and the U.K. (Labour vs Conservative). Of course, these parties can themselves be viewed as coalitions of factions such as those which exist as separate political parties in countries with different electoral and institutional systems.

It is also worth stressing that this part of the book relies to a large extent on national electoral surveys, and that many other sources should be exploited in order to develop a more detailed analysis, including local-level electoral and political mobilization data. More generally, these findings again call for a deeper study of the interplay between ideology, sociopolitical mobilization and identity. The class-based party system of the 1950-1980 period was associated to the development of a specific form of political platform, ideology and collective identity based upon working-class values and industrial work. If we turn to the future, the challenge is to build a new sense of collective identity combining the quest for social justice, gender and racial equality and environmental justice. Various mobilizations observed in recent years at the global level, especially among the youth, from Occupy Wall Street to Me Too, Black Lives Matter or Fridays for Future, suggest that new collective identities and ideologies could emerge along these lines in the future. It is clear however there are serious ideological and programmatic disagreements that are from being settled. In particular, it seems unlikely that successful environmental policies can be implement without a major transformation of the economic system and a drastic reduction in inequality.

2 Gethin/Martinez-Toledano/Piketty (eds.) 2021. 


\section{Bringing Together Economic, Social and Political History}

Let me conclude this essay with a methodological note and a call for more interdisciplinary work in the social and historical sciences. I am convinced that some of today's democratic disarray stems from the fact that, insofar as the civic and political sphere is concerned, economics has cut itself free from the other social sciences. This ‘autonomization' of economics is partly a result of the technical nature and increasing complexity of the economic sphere. But it is also the result of a recurrent temptation on the part of professional economists, whether in the university or the marketplace, to claim a monopoly of expertise and analytic capacity they do not possess. In reality, it is only by combining economic, historical, sociological, cultural, and political approaches that progress in our understanding of socioeconomic phenomena becomes possible. This is true, of course, for the study of inequalities between social classes and their transformations throughout history, but the lesson seems to me far more general.

Another factor behind the excessive autonomization of economics is that historians, sociologists, political scientists, and philosophers too often abandon the study of economic questions to economists. But political economy and economic history involve all the social sciences, as I have tried to show in this book. All social scientists should try to include socioeconomic trends in their analysis, gather quantitative and historical data whenever useful and should rely on other methods and sources when necessary. The neglect of quantitative and statistical sources by many social scientists is unfortunate, particularly since critical examination of the sources and the conditions under which they are socially, historically, and politically constructed is necessary to make proper use of them. This neglect has contributed not only to the autonomization of economics but also to its impoverishment.

In Capital and Ideology, I attempt to illustrate the complementarity between natural language and the language of mathematics and statistics. For instance, I frequently refer to deciles and percentiles when discussing inequality of income, wealth, or education. My intent is not to replace class warfare with war between the deciles. Social identities are always flexible and multidimensional. In each society various social groups use natural language to designate professions and occupations and identify the qualifications, expectations, and experiences associated with each. There is no substitute for natural language when it comes to expressing social identities or defining political ideologies. By the same token there is no substitute for natural language when it comes to doing research in social science or thinking about the just society. Those who believe that we will one day 
be able to rely on a mathematical formula, algorithm, or econometric model to determine the 'socially optimal' level of inequality are destined to be disappointed. This will thankfully never happen. Only open, democratic deliberation, conducted in plain natural language (or rather in several natural languages-not a minor point), can promise the level of nuance and subtlety necessary to make choices of such magnitude.

Nevertheless, Capital and ideology relies heavily on the language of mathematics, statistical series, graphs, and tables. These devices also play an important role in political deliberation and historical change. Once again, however, it bears repeating that the statistics, historical data, and other quantitative measures presented in this book are imperfect, provisional, tentative social constructs. I do not contend that 'truth' is found only in numbers or certainty only in 'facts.' In my view, the primary purpose of statistics is to establish orders of magnitude and to compare different and perhaps remote periods, societies, and cultures as meaningfully as possible. Perfect comparison of societies remote in space and time is never possible. Despite the radical uniqueness of every society, however, it may not be unreasonable to attempt comparisons. It may make sense, for example, to compare the concentration of wealth in the United States in 2018 with that of France in 1914 or Britain in 1800.

To be sure, the conditions under which property rights were exercised were different in each case. The relevant legal, fiscal, and social systems differed in many ways, as did asset categories (land, buildings, financial assets, immaterial goods, and so on). Nevertheless, if one is aware of all these differences and never loses sight of the social and political conditions under which the source documents were constructed, comparison may still make sense. For instance, one can estimate the share of wealth held by the wealthiest 10 percent and the poorest 50 percent in each of these three societies. Historical statistics are also the best measure of our ignorance. Citing data always reveals the need for additional data, which usually cannot be found, and it is important to explain why not. One can then be explicit about which comparisons are possible and which are not. In practice, some comparisons always make sense, even between societies that think of themselves as exceptional or as so radically different from others that learning from them is impossible. One of the main goals of social science research is to identify possible comparisons while excluding impossible ones. Comparison is useful because it can extract lessons from different political experiences and historical paths, analyze the effects of different legal and fiscal systems, establish common norms of social and economic justice, and build institutions acceptable to the majority. Social scientists too often settle for saying that every statistic is a social construct. This is of course true, but it cannot be left at that, because to do so is to abandon key debates-on economic issues, for example-to others. It is a somewhat conservative 
attitude, or at any rate an attitude that betrays deep skepticism about the possibility of deriving lessons from imperfect historical sources.

For instance, it is true that national accounts were originally developed within a specific historical context, i.e. in order to measure the growth of output at the national level. But because social and economic indicators are historically constructed, this also means that they are not bound to be tied to a productivist ideology, or the nation-state, or to the formal sector, or the lack of attention to the environment or to inequality, and so on. Most importantly, historians and all social scientists (including of course moral and political philosophers) need to be part of this discussion and to actively participate to the critical examination and redefinition of these quantitative indicators, rather than to stand safely aside.

Many historical processes of social and political emancipation have relied on statistical and mathematical constructs of one sort or another. For instance, it is difficult to organize a fair system of universal suffrage without the census data necessary to draw district boundaries in such a way as to ensure that each voter has identical weight. Mathematics can also help when it comes to defining rules for translating votes into decisions. Fiscal justice is impossible without tax schedules, which rely on well-defined rules instead of the discretionary judgments of the tax collector. Those rules are derived in turn from abstract theoretical concepts such as income and capital. These are difficult to define, but without them it is hard to get different social groups to negotiate the compromises needed to devise an acceptably fair fiscal system. In the future, people may come to realize that educational justice is impossible without similar concepts for measuring whether the public resources available to less-favored groups are at least equivalent to those available to the favored (rather than markedly inferior, as is the case today in most countries). When used carefully and in moderation, the language of mathematics and statistics is an indispensable complement to natural language when it comes to combating intellectual nationalism and overcoming elite resistance.

I very much hope that interdisciplinary dialogue will contribute to the development of a new synthesis between economic, social and political history in the future, and I want to reiterate my thanks to Analyse \& Kritik and to all participants for this very fruitful exchange.

\section{References}

Gethin, A./C. Martinez-Toledano/T. Piketty (eds.) (2021), Political Cleavages and Social Inequalities. A Study of 50 Democracies, 1948-2020, Cambridge/MA

Goody, J. (2006), The Theft of History, Cambridge

Piketty, T. (2020), Capital and Ideology, Cambridge/MA 